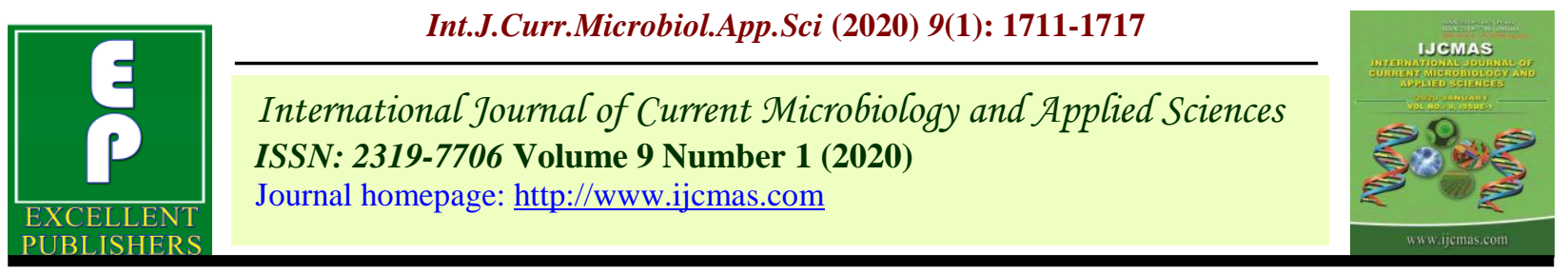

Review Article

https://doi.org/10.20546/ijcmas.2020.901.189

\title{
Traditional and Medicinal Importance of Sapota - Review
}

\author{
M. Baskar*, G. Hemalatha and P. Muneeshwari \\ Department of Food Science and Nutrition, Community Science College and Research \\ Institute, TNAU, Madurai-625 014, India \\ *Corresponding author
}

Keywords

Sapota, Chemical, Nutrient, Uses

Article Info

Accepted:

15 December 2019

Available Online:

20 January 2020

A B S T R A C T

Sapota (Achras sapota L.) belongs to the family Sapotaceae. Sapota is one of the major Fruit crop grown in India. The nutrient value of sapota fruit $(100 \mathrm{~g})$ includes $0.4 \mathrm{~g}$ of protein, $1.1 \mathrm{~g}$ of fat, $20 \mathrm{~g}$ of carbohydrate, $5.3 \mathrm{~g}$ of total dietary fiber, $210 \mathrm{mg}$ of calcium, $0.8 \mathrm{mg}$ of iron, $12.0 \mathrm{mg}$ of magnesium, $12.0 \mathrm{mg}$ of phosphorus, $193.0 \mathrm{mg}$ of potassium, $12.0 \mathrm{mg}$ of sodium and $14.7 \mathrm{mg}$ of vitamin C. Sapota, commonly known as Chickoo has a sweet taste that resembles a mixed flavour of brown sugar and beet root. It is liked by people of all ages and is a most popular fruit in Asia. It also has chemical compounds like sugar, protein, ascorbic acid, phenolics, carotenoids, glycoside sapotinine and minerals like iron, copper, zinc, calcium and potassium. It is an excellent nutrient useful in the management of many diseases like inflammation, pain, diarrhoea etc. Traditionally, it is used as a diuretic, expectorant and in ophthalmology. This article reviews distribution of Achras zapota plant, its chemical constituents, traditional and medicinal importance.

\section{Introduction}

Sapota is a tropical fruit. It is believed to be native to Yucatan and possibly other nearby parts of southern Mexico, as well as northern Belize and north-eastern Guatemala. It is believed that sapota was cultivated throughout tropical America, West Indies and southern part of Florida mainland, where it is a tall tree found in forests. Early in colonial times, it was carried to Philippines by the Spanish and later was adopted everywhere in the Old World tropics. From the Philippines, it spread throughout Southeast Asia as a popular fruit tree, where it is not only consumed but also exported. It reached Sri Lanka in 1802. Sapota was introduced to India in 1898. Various species of sapota are now cultivated in Africa, India, East Indies, Philippines, Malaysia, Thailand, the tropical and subtropical regions of America and in almost all tropical countries worldwide. 
Sapota plant is usually grown in tropical areas, but can also be grown in semi-tropical areas in green-house. It can be grown up to $1200 \mathrm{~m}$. above sea level. Being a tropical fruit, it needs warm $\left(10-38^{\circ} \mathrm{C}\right)$ and humid climate $(70 \%$ relative humidity) for growth. Alluvial, sandy loam, red laterite and medium black soil having good drainage system, with acidic to neutral $\mathrm{pH}$, provide best environment for sapota. For good yield, fertilizers containing 6-8\% nitrogen, $2-4 \%$ phosphoric acid and 6- 8\% potash every 2-3 months and increasing gradually to $250 \mathrm{~g}$ per plant are used in the first two years. In after second year, 2 to 3 applications per year prove to be sufficient. Very little pruning is required for the plant.

Mostly sapota are picked un-ripe. At normal summer temperature and relative humidity $(\mathrm{RH})$, the hard and immature sapota ripen within 9 - 10 days and rot in two weeks but extremely low temperature seriously retards the ripening of the fruit and damages its quality. Low relative humidity causes the fruit to wrinkle and shrivel up and extreme humidity causes sogginess. Sapota can be stored for long under proper conditions. Harvested fruits can be stored for 2 to 3 weeks at 12 to $16^{\circ} \mathrm{C}$ with 85 to $90 \% \mathrm{RH}$. The fruits can also be stored with $5 \% \mathrm{CO} 2$ for 18 days at normal temperature. Fully matured/ripe fruits can be kept at a temperature of $1.67^{\circ} \mathrm{C}$ for as long as six weeks.

\section{Geographical distribution}

Cultivation of sapota is done in the warm and humid areas of the world. It is indigenous to southern Mexico, Yucatan Peninsula, Central America and South America. It is very popular in Asian countries like Phillipines, Sri Lanka, Thailand, Malaysia and India. In India, sapota is grown in several states including Tamil Nadu, Andhra Pradesh,
Maharashtra and Gujarat.

\section{Phytoconstituents of sapota}

The plant contains several phytochemical constituents belonging to categories such as alkaloids, carbohydrates, glycosides, tannins, triterpenes and flavonoids etc. It also contains amino acids, proteins, ascorbic acid, phenols, carotenoids and minerals like iron, copper, zinc, calcium and potassium. Vitamins are also present in substantial quantity which make Chickoo a useful cosmetic. The concentration of constituents varies in leaves, fruits, latex seeds and bark. Major constituents isolated from fruits of $M$. zapotaare polyphenols.

\section{Antioxidant activity}

Md. Raficul Islam and co-workers stated that it was found to be more potent in comparison to known antioxidant.

\section{Antibacterial activity (Kotharis et al., 2010)}

Vijay Kothari and co-workers has stated that acetone extracts of Manilkara zapota and Tamarindus indica and methanolic extract of Tamarindus indica were found to have significant antibacterial in comparison to standard drug used as streptomycin and ofloxacin.

\section{Antimicrobial activity (Nair et al., 2008)}

R. Nair and coworkers has reported that methanolic extract was found to be more effective than aqueous extract with regard to standard drug used as piperacillin and gentamycin for antibacterial while fluconazole for antimicrobial activity.

\section{Antifungal activity}

Osman et al., (2011) stated that Five fungal 
strains (Aspergillus flavus, Aspergillus fumigatus, Candida albicans, Vasian factum and Fusarium) were used to test antifungal activity. Stem bark extract showed antifungal activity against Aspergillus flavus, Fusarium and Vasian factum. The antifungal activity is probably due to the presence of terpenoids, flavonoids and glycosides.

\section{Antitumor activity}

Rasid et al., 2014., reported that Sapota remarkably increased the $\mathrm{RBC}$ count and haemoglobin content bur reduced the WBC count in mice. The average life span of animals was increased with consuming sapota. This anticarcinogenic property of Manilkara zapota was probably due to the presence of saponin.

\section{Anti-inflammatory and antipyretic activity}

Inflammation is associated with histamine or serotonin release in first phase and formation and release of prostaglandin in the second phase. Anti-inflammatory activity of Manilkara zapota may be due to inhibition of release of histamine and serotonin. Inhibition of biosynthesis of prostaglandins by inhibiting cyclooxygenase pathway may also contribute for both anti-inflammatory and anti-pyretic activities. Anti- inflammatory and anti-pyretic activities of the leaves of the plant could be attributed to the active constituents like lupeol acetate, oleanolic acid; apigenin-7-O- $\alpha$-Lrhamnoside and myricetin-3-O- $\alpha-\mathrm{L}$ rhamnoside present in the Manilkara zapota leaves (Ganguly et al., 2013 and Hossain et al., 2012) .

\section{Analgesic activity}

Availability of alkaloids, polyphenols and flavonoids in sapota plant as chemical constituents contribute for its potent analgesic activity. Mechanism of analgesic activity appears to be related to desensitization of nociceptors and non-selective inhibition of cyclooxegenase pathway (Jain et al., 2011). It can be used as both central and pheripheral analgesic (Manirujjaman et al., 2014).

\section{Hepatoprotective effect}

Hepatoprotective activity of Manilkara zapota is based on its strong antioxidant activity due to the presence off lavonoids, carotenoids and ascorbic acid in sapota (Islam et al., 2010, 2012).

\section{Hypocholesterolemic effect}

Compounds identified as lupeol acetate, oleanolic acid, apigenin-7-O- $\alpha$-Lrhamnoside, myricetin-3-O- $\alpha$-L-rhamnoside and caffeic acid from the petroleum ether and ethyl acetate fractions of the alcoholic extract of the leaves of Manilkara zapota exhibited the hypo cholesterolemic effect (Fayek, 2012).

\section{Hypoglycaemic activity}

The presence of phytochemical constituents like saponin, sapotin, achras saponin and the bitter principle sapotinine in Manilkara zapota seed have antidiabetic effect. The ethanolic extract of Manilkara zapota having dose $400 \mathrm{mg} / \mathrm{kg}$ was found to be toxic in rats whereas, aqueous extract and lower dose of ethanolic extract was found to besafe (Saratha et al., 2014).

\section{Antidiarrhoeal activity}

The antidiarrhoeal activity of the extract may be due to the increase of there-absorption of electrolytes and water from gastrointestinal tract or inhibition of prostaglandin biosynthesis. Antidiarrhoel effect may be seen due to the presence of flavonoids and saponins (Manirujjaman et al., 2013). 


\section{Tyrosinase and elastase inhibitor effect}

Tyrosinase and elastase inhibitory effect has been seen in methanolic extract of Manilkara zapota, which may be due to the presence of myricitrin or myricetin-3-O- $\alpha$-Lrhamonoside. Tyrosinase (Phenol oxidase) is a key enzyme that catalyzes melanin synthesis in plants, microorganisms and mammalian cells.

Tyrosinase inhibitors have been tested in cosmetics and pharmaceuticals (alkaptonuria) as a way of preventing over production of melanin in epidermal layers. Elastase inhibitory activity can work as an anti-ageing agent (Rao et al., 2014).

\section{Traditional uses of sapota}

The fruits and crushed seeds of sapota are used in preventing oedema due to diuretic property. They also prevent formation of kidney and bladder stones.

The latex content of sapota fruit is used as a material for filling tooth cavities.

The Sapota fruit reduces inflammation and pain in gastritis, reflux oesophagitis and bowel disorders. Paste of seeds of sapota is used to alleviate pain and inflammation due to stings and bites. Sapota strengthens the intestines, boosts immunity and prevents from many bacterial infections due to presence of VitaminC.

It is useful in pregnancy due to its high nutritional content. It reduces weakness, nausea and dizziness and prevents anaemia.

A decoction of the bark and fruit is used for fevers and diarrhoea. Tea made of the bark also treats dysentery. It is also useful in constipation and piles.
The fibre and vitamin A content of sapota fruit prevents colon cancer, lung cancer, and oral cavity cancers.

A paste of the mixture of sapota flowers and fruits relieves as well as prevents the respiratory disorders.

Sapota fruit is also a good anti-spasmodic agent.

\section{Cosmetic value of sapota}

Sapota, being rich in nutrients can be used as a herbal remedy for skin infections and particularly for beauty enhancement.

The Vitamins E, A and C of the fruit Achras zapota, makes the skin healthy due to its moisturising effect.

Presence of antioxidant like ascorbic acid, polyphenols and flavonoids help in reducing wrinkles.

Warts and fungal growth on the skin is cleared away by the milky sap of the sapota plant. The seed oil helps in moisturizing the scalp and softening hair.

It yields beneficial results in the management of curly hair.

The sapota seed oil helps in treating hair-fall due to seborrheic dermatitis.

\section{Miscllaneous uses of sapota}

Besides having medicinal, nutritional and culinary uses, sapota tree has several other uses, which enhance its utility.

Chickle (latex of the sapota tree) is a base material for chewing gum and is used as an adhesive in repairing goods in India. 
This gum-latex of the plant Manilkara is also used in dental surgeries and making transmission belts.

Being strong and durable, the sapota wood is used to prepare flooring, wooden carts, tool handles and railway crossties.

Some other materials like archer's bows, furniture, banisters etc are also manufactured from the red heartwood of plant.

Philippine fisherman uses bark of the sapota plant to stain their sails and fishing lines. Coffin is made out of timber of a species of Manilkara genera, Manilkara kauki in Malaya.

\section{Adverse effects}

Half-a-dozen seeds of sapota are consumed, stomach pain is experienced due to the presence of sapotine and sapotinin. Raw sapota fruits contains high amount of latex and tannins, which contribute to its extremely bitter taste. Mouth ulcers, prickling in the throat, and dyspnoea, especially in small children is observed upon eating of raw fruits.

\section{Strange facts}

Fruits of sapota do not ripe until they are picked. Chickoo is fried or stewed with lime juice or ginger in Indonesia and Malaya. The sawdust of sapota plant is irritating to the nostrils. Dishes containing sapota comprise of fresh Fruit slices, Breads, Muffins, Milkshakes, Ice creams, Sweet sauce, Pies, Jellies and Syrups. Sapota fruit is a favourite dish of many Birds and bees. Fruit in the form of syrup, is stored in Bahams. Wine can also be made from the sapota fruit. Young and leafy shoots of the sapota plant are eaten raw or steamed with rice after removing the sticky sap in Indonesia.

\section{Application of sapota in various fields}

The fruit and crushed seed of sapodilla are used in prevent in oedema due to diuretic and bladder stores. Many year the latex from the sapota tree called chick was the main ingredient of chewing gum. It contains $15 \%$ rubber and $38 \%$ resin and it's tasteless. Steps to process the latex into chewing gum drying melting, eliminator of foreign matter mixing with other gum, sweetness and flavor and finally rolling into sheets and cutting in to different sizes. (Morton, 1987)

The wood Form the sapodilla tree is dark red, hard, heavy and durable and has been used for Railway cross-trees, flooding tool handles, etc. The sapota red heart wood is also valued for Furniture, banisters and cabinet work (Garcia, 1988).

Value added products from sapota (Reddy, 1959) such as sapota squash, jam, slices, butter, cheese, candy, milk shake, powder, biscuit, ice cream, shrikhand, pulp, juice, sweetchutney, dried sapota flakes, sapota milk shake,osmo-dehydrated sapota slices, nectar, lassie, chocolate, bar, chewing gum , toothy fruity, ready to serve beverage, spray dried powder, concentrate, carbonated berverage and fermented beverage (wine).

In conclusion, sapota is regarded as a natural energy booster as it contains fructose and sucrose. India's sapota production is higher in the world; hence its market value in India is less. Sapota is a delicious fruit and every part of the sapota plant has several medicinal and cosmetic properties. Medicinal properties of sapota are due to chemical constituents such as polyphenols, ascorbic acid, glycoside sapotinine etc. It is an excellent nutrient useful in the management of many diseases like inflammation, pain, diarrhoea etc. It can also be used in cosmetics. Traditionally, it is used as a diuretic, expectorant and in 
ophthalmology. Sapota constitutes maximum post harvest losses. Value added products such as juice, vinegar, jam and wine increases the economic value of the sapota. These value added products highly accepted in all over the world by consumers in every group and also have high medicinal uses such as controlling diabetes. Shelf life of the value added products are higher than fresh sapota fruits. Sapota products are available throughout the year. Which increases the economical level of the farmers hence the value added product preparation from sapota is beneficial.

\section{References}

Ahmed R, Ifzal SM and Zaidi ZH. Studies on AchrasSapota L. Part II (1982). The Chemical Constituents of the Leaves of Achras Zapota. J ChemSoc Pak ;4(3):171-173.

Awasare S, Bhujbal S, Nanda R. (2012) In Vitro Cytotoxic activity of novel oleanane type of triterpenoid saponin from stem bark of Manilkara Zapota Linn. Asian J Pharm Clin Res ;5(4):183188.

Fayek NM, Monem ARA, Mossa MY, Meselhy MR, Shazly AH. (2012) Chemical and Biological Study of ManilkaraZapota (L.)Van Royen (Sapotaceae) Cultivated in Egypt. Pharmacognosy Res ; 4(2):8591.http://dx.doi.org/10.4103/09748490.94723

Ganguly A, Mahmud ZA, Nassiruddin MM, Rahman SMA. 2013. In-vivo antiinflammatory and anti-pyretic activities of Manilkara zapota leaves in albino Wistar rats. Asian Pac J Trop Dis 2013; 3(4):301-

307.http://dx.doi.org/10.1016/S22221808(13)60073-0

Hossain MH, Jahan F, Howlader MSI, Dey SK, Hira A, Ahmed A, Sarkar RP. (2012) Evaluation of Anti-inflammatory
Activity and Total Flavonoids Content of Manilkarazapota (Linn.) Bark. eIJPPR ; 2(1):35-39

Islam MR, Parvin MS, Hasan MR, Islam ME. (2010). In vitro And In vivo Antioxidant Activity of EthanolicExtact of Manilkarazapota bark. Journal of Global Pharma Technology ;2(11):23-30.

Islam MR, Parvin MS, Islam MS. Hasan SMR, Islam ME. (2012) Antioxidant Activity of the Ethanol Extract of ManilkarazapotaLeaf. J Scientific Res; 4(1):193-202.

Jain PK, Soni P, Upmanyu N, Shivhare Y. (2011). Evaluation of Analgesic Activity of ManilkaraZapota (Leaves). Eur J ExpBiol ; 1(1):14-17.

Kothari, V. and S. Seshadri, (2010). In-vitro antibacterial activity in seed extracts of Manilkara zapota, Anona squamosa and Tamarindus indica. Biol Res, 43: 165168.

Manirujjaman, Sultana F, Chowdhury MAR, Hossain MT and Imran-ul-haque M. (2014). In Vivo Assay of Analgesic Activity of Methanolic and Petroleum Ether Extracts of ManilkaraZapota Leaves. Br J Pharm Res ; 4(2):186191.http://dx.doi.org/10.9734/BJPR/201 $4 / 5941$

Manirujjaman, Sultana F, Chowdhury MAR, Shimu MC, Hossain MT, Imran-UlHaque M. (2013). In Vivo assay of Antidiarrhoeal activity of Methanolic and Petroleum ether extracts of Manilkara Zapota Leaves. Int J Drug Dev Res ;5(4):164-171

Mathew AG, Lakshminarayana S. (1969). Polyphenols of immature sapota fruit. Phytochemistry ; 8:507-509. http://dx.doi.org/ 10.1016/S00319422(00)85457-6

Nair, R. and S. Chanda, (2008). Antimicrobial activity of Terminalia catappa, Manilkara zapota and Peper betel leaf extract. Indian journal of 
pharmaceutical sciences, 70(3): 390393.

Osman MA, Aziz MA, Habib MR, Karim MR. (2011) Antimicrobial Investigation on Manilkara zapota(L.) P. Royen. Int J Drug Dev Res ;3(1):185-190.

Rao GV, Sahoo MR , Madhavi MSL, Mukhopadhyay T. 2014. Phytoconstituents from the leaves and seeds of Manilkara zapotaLinn. Der Pharmacia Lettre ; 6(2):69-73

Rashid MM, Hossain MI, M, Osman, MA, Aziz MA, Habib MR, Karim MR. (2014) Evaluation of antitumor activity of Manilkara zapota leaves against Ehrlich ascites carcinoma in mice. Environ Exp Biol ;12:131-135.

Reddy MG. (1959) Physico-chemical investigation on sapota and its product M.Sc. The sis CFTRI Research Instule, Musore.
Sakala B, Buthapalli K, Dantu KS, Buchiraju R, Sreekanth N. (2013)An evaluation of the antibacterial activity of root extracts of Manilkara Zapota against Staphylococcus Aureus and Escherichia coli. Int J Phytopharmacol ; 4(3):171173.

Saradha S, Ruckmani A, Chokkalingam M, Maignanakumar R, Arunkumar R, Madhavi E, Lakshmipathyprabhu R. (2014) Hypoglycaemic activity of aqueous and ethanolic extracts of manilkara zapota seeds in steptozotocin induced diabetic rats. Int $\mathrm{J}$ Pharm PharmSci ; 6(2):434-437.

Selvaraj Y, Pal DK. (1984) Changes in the chemical composition and enzyme activity of the two-sapodilla cultivars during development and ripening. $\mathbf{J}$ Hortic Sci Biotech; 59: 275-281.

\section{How to cite this article:}

Baskar, M., G. Hemalatha and Muneeshwari, P. 2020. Traditional and Medicinal Importance of Sapota - Review. Int.J.Curr.Microbiol.App.Sci. 9(01): 1711-1717. doi: https://doi.org/10.20546/ijcmas.2020.901.189 